\title{
Manart: A Database of Twentieth-Century Artistic and Literary Manifestos
}

Manart: une base de données sur les manifestes artistiques et littéraires au XXe siècle

Manart : una base de datos sobre las manifestaciones artística y literarias del siglo XX

Camille Bloomfield, Viviana Birolli, Mette Tjell and Audrey Ziane Translator. Michelle Arriss, Delaina Haslam and Séverine Sofio

\section{OpenEdition Journals}

Electronic version

URL: http://journals.openedition.org/bssg/238

DOI: $10.4000 /$ bssg.238

ISSN: 2490-9424

Publisher

Presses universitaires de Vincennes

\section{Electronic reference}

Camille Bloomfield, Viviana Birolli, Mette Tjell and Audrey Ziane, "Manart: A Database of Twentieth-

Century Artistic and Literary Manifestos ", Biens Symboliques / Symbolic Goods [Online], 2 | 2018, Online since 10 February 2021, connection on 04 March 2021. URL: http://journals.openedition.org/bssg/238 ; DOI: https://doi.org/10.4000/bssg.238 


\title{
Manart : une base de données sur les manifestes artistiques et littéraires au $x x^{e}$ siècle

\author{
Manart: A Database of Twentieth- \\ Century Artistic and Literary \\ Manifestos
}

\author{
Camille Bloomfield \\ traduction | translation \\ Michelle Arriss | Delaina Haslam | Séverine Sofio
}

\section{Comment est né le projet de base de données ?}

Le projet Manart est né en 2012 lors de la journée d'études « Le manifeste artistique. Un genre collectif à l'ère de la singularité " organisée à l'École des hautes études en sciences sociales (EHESS). Une première base regroupant des manifestes artistiques et littéraires produits au $\mathrm{XX}^{\mathrm{e}}$ siècle, en France et dans le monde, y avait été présentée par Camille Bloomfield. Peu après, l'équipe s'est constituée avec les deux organisatrices de la journée, Viviana Birolli et Mette Tjell, et l'une des intervenantes, Audrey Ziane, toutes travaillant déjà sur l'histoire et l'évolution du manifeste en art et en littérature.

Le projet a d'abord reçu un soutien de principe du centre Hubert de Phalèse (au sein du laboratoire Écritures de la modernité, Université Paris 3), spécialisé sur les rapports entre informatique

\section{How did the database project begin?}

The Manart project began in 2012 during the seminar entitled "The Artistic Manifesto: A Collective Genre in the Era of the Individual," organized at the École des hautes études en sciences sociales (EHESS). An initial database that brought together artistic and literary manifestos of the twentieth century from France and rest of the world, was presented by Camille Bloomfield. Shortly afterwards, the team was created with the two seminar organizers, Viviana Birolli and Mette Tjell, and one of the participants, Audrey Ziane, all of whom were already working on the history and evolution of the manifesto in art and literature.

The project first received support in principle from the Centre Hubert de Phalèse (part of the laboratory Écritures de la modernité, Université Paris 3) specialized in relationships between computing 
et littérature, et du Centre de recherches sur les arts et le langage (CRAL, EHESS), laboratoire favorable à une approche sociologique du fait artistique et littéraire. Pendant trois ans, les quatre chercheuses impliquées dans le projet ont travaillé sans soutien financier institutionnel. C'est seulement en 2014 que le laboratoire d'excellence Création Arts Patrimoines (Labex CAP a accordé au projet un financement pour un an, qui a permis le développement informatique de la base et sa publication sur le site basemanart. com, grâce à l'aide de programmeurs et designers web.

Aujourd'hui, le projet est soutenu par le laboratoire Pléiade de l'Université Paris 13 (Villetaneuse), auquel est rattachée Camille Bloomfield, et par le projet fédératif « Délivrez-nous du livre » dans la même université. Dans ce cadre, il continue d'évoluer à la fois techniquement et scientifiquement, notamment par l'intermédiaire de l'Atelier Manart, un séminaire de recherche soutenu par le Campus Condorcet qui s'est déroulé de janvier à juin 2017 à Paris. Grâce à cet atelier et à la nature collaborative du site, le projet tend désormais à accueillir une communauté de chercheurs susceptibles d'enrichir la base en fonction de leur spécialité disciplinaire ou géographique.

La base Manart recense des manifestes produits au $\mathrm{XX}^{\mathrm{e}}$ siècle dans le monde, dans tous les domaines de la création : continuellement en expansion, la base comptait 725 manifestes au $1^{\mathrm{er}}$ avril 2017. Les informations à la fois descriptives et analytiques rassemblées dans la base autorisent désormais des questionnements qui contribuent à élargir et à nuancer les perspectives d'analyse du manifeste comme genre. Quelle part le manifeste fait-il à l'individu et au collectif ? A-t-il connu un «âge d'or », comme on le croit souvent ? Où produit-on le plus de manifestes ? Quels supports matériels ont été privilégiés par les artistes pour communiquer leurs programmes? and literature, and from the Centre de recherches sur les arts et le langage (CRAL, EHESS), a laboratory favourable to sociological approaches of arts and literature. For three years, the four researchers involved in the project worked without any institutional subsidy. It was only in 2014 that the Laboratoire d'excellence "Création Arts Patrimoines" (Labex CAP) granted funding for the project for one year, which enabled the computerized development of the database and its publication on the basemanart.com website with the help of programmers and web designers.

Today, the project is supported by the laboratory Pléiade of Université Paris 13 in Villetaneuse, to which Camille Bloomfield is attached, and by the "Délivrez-nous du livre" ("The Book After the Book") federative project at the same university. It continues to evolve technically and scientifically within this framework, particularly with the Atelier Manart (Manart Workshop), a research seminar supported by the Campus Condorcet, which took place from January to June 2017 in Paris. Now, thanks to this workshop and to the collaborative nature of the website, the project welcomes a community of researchers open to enriching the database according to their disciplinary or geographical specialty.

The Manart database records manifestos produced worldwide in the twentieth century in every area of creativity. Continually under expansion, the database included 725 manifestos as of 1 April 2017. Information that is both descriptive and analytical collected in the database allows searches that contribute to the expansion and nuancing of analytical perspectives of the manifesto as a genre. Which part of the manifesto was made individually and which collectively? Did it experience a "golden age," as is often believed? Where are most manifestos produced? Which media were privileged by artists to communicate their programmes? 


\section{Comment le corpus a-t-il été délimité ?}

La question de la constitution du corpus a été aussi passionnante que complexe à résoudre. À la fois texte et geste, le manifeste est une forme qui se laisse difficilement circonscrire. Se limiter à une simple définition serait insuffisant, car cela présupposerait l'existence d'un idéal-type du manifeste - existence qui reste à prouver. Or, dans la mesure où il revendique une position nouvelle dans les arts, le manifeste est toujours conditionné par l'état du champ artistique à l'époque de sa publication et relève d'une grande variété de formes et de discours. Dès lors, comment systématiser un genre aussi fluctuant et « indiscipliné » ?

Pour être inclus dans la base, chaque document doit remplir au moins l'une des trois conditions suivantes : 1/ afficher une revendication explicite d'appartenance au genre du manifeste ( "manifeste de... » ou « pour un... », etc.) ; 2/ correspondre à une définition générale du manifeste ${ }^{1} ; 3 /$ avoir été reçu comme manifeste par au moins un spécialiste dans le domaine.

Ces trois critères ne servent pas uniquement à délimiter un corpus. Le moteur de recherche avancé permet aussi à chaque utilisateur de faire des requêtes en délimitant son corpus en fonction de ses objectifs de recherche : si l'on s'intéresse à la dynamique du champ artistique, une sélection large est préférable, car elle permet d'inclure, par exemple, des textes non collectifs, exprimant un positionnement individuel. $\mathrm{Si}$, au contraire, on s'interroge sur la définition du manifeste, une sélection plus restreinte est intéressante, dans la mesure où elle rend possible une étude de l'évolution des traits distinctifs du genre (Bloomfield \& Tjell 2013).

1 Nous avons adopté comme définition de référence celle du Dictionnaire

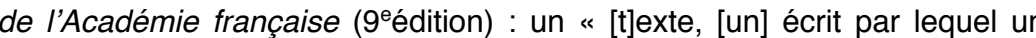
mouvement littéraire ou artistique expose ses intentions, ses aspirations ».

\section{How was the corpus defined?}

The question of what the corpus would contain was as passionate as it was complex to resolve. As both text and act, the manifesto is a form that is difficult to delimit. To be restricted to a simple definition would be insufficient because that would assume the existence of an ideal type of manifesto - an existence that remains to be proven. Moreover, in the sense that it asserts a new stance in the arts, the manifesto is always conditioned by the state of the artistic field in the era of its publication and takes on a vast variety of forms and discourses. In view of this, how can such a fluid and "undisciplined" genre be systematized?

In order to be included in the database, each document must meet at least one of the following three conditions: 1) include an explicit assertion of belonging to the manifesto genre ("manifesto of..." or "for a ...," etc.); 2) correspond to a general definition of a manifesto; ${ }^{1} 3$ ) have been accepted as a manifesto by at least one specialist in the field.

These three criteria don't only serve to determine a corpus. The advanced research engine also allows each user to conduct searches by determining his or her corpus in terms of his or her research objectives: if $\mathrm{s} / \mathrm{he}$ interested in the dynamics of the artistic field, a large selection is preferable because this allows the inclusion of, for example, non-collective texts that express an individual stance. If, on the other hand, s/he is wondering about the definition of the manifesto, a more limited selection is interesting, in the sense that it makes a study of the evolution of the genre's distinctive traits possible (Bloomfield \& Tjell 2013).

1 We have adopted as our reference definition that of the Dictionnaire de l'Académie française ( $9^{\text {th }}$ edition): a "[t]ext or piece of writing in which a literary or artistic movement expresses its intentions or aspirations." 
La détermination des bornes chronologiques de la base a été un autre questionnement majeur. Un point de départ a été fixé en 1886, date de la parution dans Le Figaro du "Symbolisme » de Jean Moréas, qui a donné lieu à une vague de productions manifestaires émanant de groupes de poètes et d'artistes. La base Manart n'a en revanche pas de date de fin, afin que l'équipe puisse suivre l'évolution du genre au fil du temps et en interroger les formes les plus récentes.

Le pays de production et l'appartenance disciplinaire des manifestes recensés ne font l'objet d'aucune limitation. Inclure des manifestes relevant de l'ensemble des disciplines artistiques et de toutes les aires géographiques permet notamment d'évaluer le caractère transdisciplinaire et transnational d'un mouvement et de comparer les caractéristiques discursives et formelles du manifeste d'une discipline et d'un pays à l'autre. Le manifeste n'est-il pas le seul genre dont se sont emparés les artistes et les théoriciens de tous les domaines de la création ? Deux variables ont ainsi été adoptées, qui peuvent être croisées : le pays de parution de la première version du manifeste et la langue dans laquelle il est paru.

\section{Quels logiciels avez-vous utilisés pour bâtir l'infrastructure de la base de données et, le cas échéant, pour son exploitation statistique?}

La base Manart a été développée d'abord sur un tableur classique (format .xIs), pour ensuite être convertie en XML en vue de sa publication en ligne sur le premier site du projet, construit avec Joomla. C'est finalement la plateforme Drupal qui a été choisie pour la deuxième version, en raison de ses plus grandes potentialités techniques. Les entrées de la base sont donc des "contenus" Drupal, reliés à une base de données au format SQL.
Determining the chronological framework of the database was another major challenge. A starting point was set at 1886 , the date of publication of Jean Moréas's "Symbolisme," in Le Figaro, which led to a wave of manifesto productions emanating from groups of poets and artists. The Manart database does not propose an end date, so that the team is able to follow the evolution of the genre over time and consult its most recent forms.

The country of production and the disciplinary field to which the recorded manifestos belong are not restricted in any way. Including manifestos relevant to all artistic disciplines and all geographical areas allows, in particular, evaluation of the transdisciplinary and transnational nature of a movement, and comparison of the discursive and definitive characteristics of the manifesto from one discipline and one country to another. Is the manifesto not the only genre which artists and theoreticians of all creative fields have seized upon? Two variables which can be cross-referenced have therefore been adopted: the country in which the first version of the manifesto appeared and the language in which it appeared.

\section{Which software programs were used to build the database infrastructure and, as the case may be, to treat the data statistically?}

The Manart database was first developed using a standard spreadsheet (.xls format), and then converted into XML for its online publication on the project's first website, built using Joomla. In the end, the Drupal platform was chosen for the second version because of its broader range of technical possibilities. The database's entries are therefore Drupal "content," linked to a database in SQL format. 
Un moteur de recherche intégré permet de faire des requêtes fines dans les contenus, tandis que des pages standard présentent le protocole de recherche, l'historique et les actualités du projet. Pour permettre l'usage collaboratif, seuls les utilisateurs enregistrés peuvent proposer de nouveaux manifestes ou suggérer des modifications sur

des notices existantes.

Les prochains chantiers envisagés sont : l'affichage de visuels pour les notices (fac-similés des manifestes) ; l'océrisation des textes eux-mêmes pour permettre une recherche en plein texte dans le corpus, et l'export des résultats de recherche, associé à des outils de visualisation de données (statistiques). Pour l'instant, seule l'équipe du projet peut avoir accès aux exploitations statistiques des résultats.

\section{Pourriez-vous donner en exemple un ou deux résultats scientifiques (attendu ou surprenant) obtenus à l'aide de la base de données ?}

Dans la mesure où cette plate-forme tend à effacer la distinction entre des textes qui ont fait date et d'autres passés plus inaperçus, Manart favorise des approches qui s'écartent des visions téléologiques de l'histoire littéraire ou artistique véhiculées par les anthologies de manifestes. À titre d'exemple, quelqu'un qui s'intéresse àl'évolution du genre au $x x^{e}$ siècle au sein des différentes disciplines pourrait conduire une recherche sur le paramètre du domaine artistique dans l'ensemble de la base. La catégorie "Art », qui regroupe la majorité des manifestes comme le montre le graphique ci-dessous, réunit des manifestes transdisciplinaires qui étaient particulièrement fréquents dans la période des avantgardes historiques du début du $\mathrm{xx}^{\mathrm{e}}$ siècle. Si le graphique oblitère cet aspect temporel, une telle recherche permet en revanche de mettre en valeur l'impressionnante interdisciplinarité qui fait la
An integrated research engine enables detailed searches in the content, while standard pages offer the project's research protocol, history, and project-related news items. In order to allow collective use, only registered users can propose new manifestos or suggest changes to existing entries.

The next worksites under consideration are: display of visual contents for entries (facsimiles of the manifestos); OCR processing of the texts themselves to enable full-text searches, and the export of research results associated with data display tools (statistics). For now, only the project's team members can have access to statistical treatments of the results.

\section{Could you offer one or two examples of scientific (whether consensual or surprising) results obtained with the help of the database}

In so far as this platform tends to erase the distinction between seminal historic texts and others more easily overlooked, Manart privileges approaches that distance themselves from teleological visions of literary or artistic history conveyed by anthologies of manifestos. For example, someone who is interested in the evolution of the genre in the twentieth century within different disciplines could carry out a search on the parameters of the artistic field in the entire database. The "Art" category, which aggregates the majority of the manifestos as shown in the graph below, assembles transdisciplinary manifestos that were particularly frequent in the period of the historical avant-garde at the beginning of the twentieth century. While the graph obliterates this temporal aspect, such a search reveals the impressive interdisciplinarity which makes the specificity of the genre, as well as areas in which 
particularité du genre, ainsi que de découvrir des domaines où les évolutions du manifeste ont été relativement peu explorées l'architecture, le cinéma et la bande dessinée, entre autres. evolutions of the manifesto have not yet been much explored - architecture, cinema, and comic strips, among others.

\section{Nombre de mentions d'un domaine dans la base Manart}

Figure 1. Extrait de Manart par C. Bloomfield et A. Ziane (29 mars 2016*)

* La variable retenue est le domaine

d'appartenance. À un manifeste

peuvent correspondre plusieurs

domaines, d'où l'impossibilité

d'exprimer ces résultats

en pourcentage. La base contenait

alors 725 entrées.

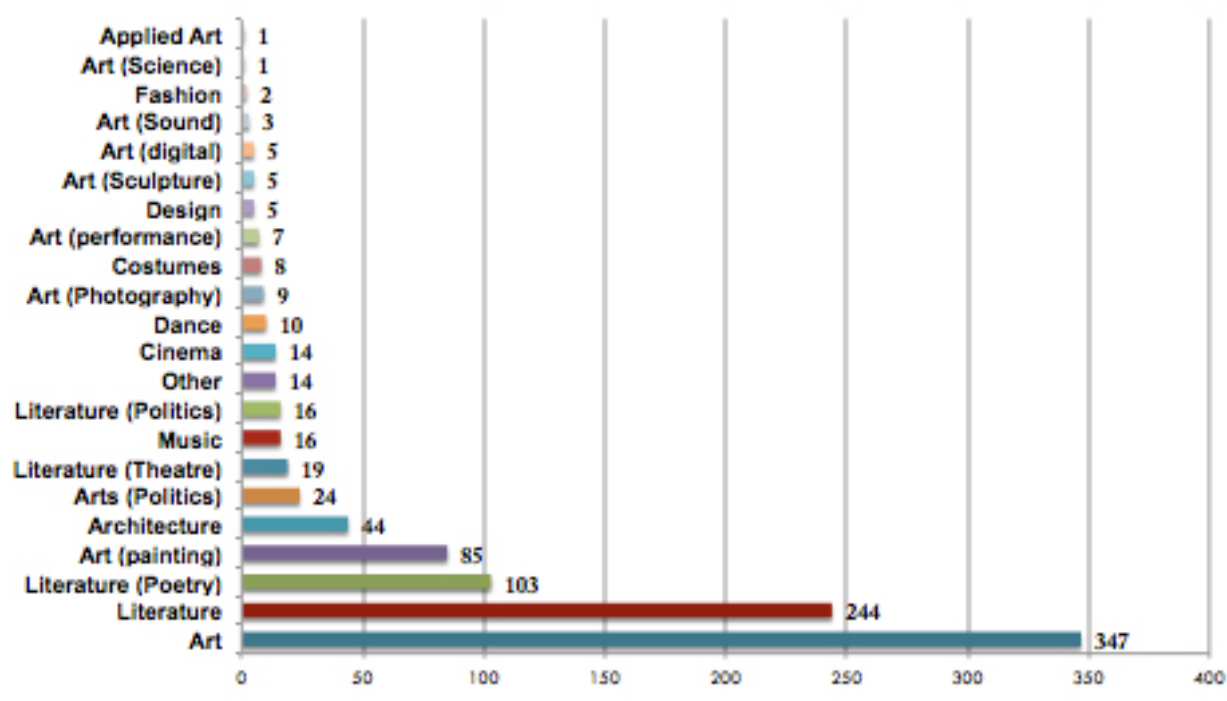

Figure 1. Data retrieved from Manart

by $\mathrm{C}$. Bloomfield and $\mathrm{A}$. Ziane

(29 March 2016*)

'The field of appearance was

the variable used. Several fields

correspond to one manifesto, hence

the impossibility of expressing these

results as a percentage. The database contained 725 entries at the time.

Des recherches peuvent aussi porter sur les propriétés internes du genre : il est par exemple possible de visualiser la proportion de manifestes produits à titre individuel ou collectif, comme le montre le graphique suivant, constitué à partir d'un corpus de 207 manifestes parus en France.

Des recherches peuvent aussi porter sur les propriétés internes du genre : il est par exemple possible de visualiser la proportion de manifestes produits à titre individuel ou collectif, comme le montre le graphique suivant, constitué à partir d'un corpus de 207 manifestes parus en France. 
Figure 2. Extrait de Manart par M. Tjell

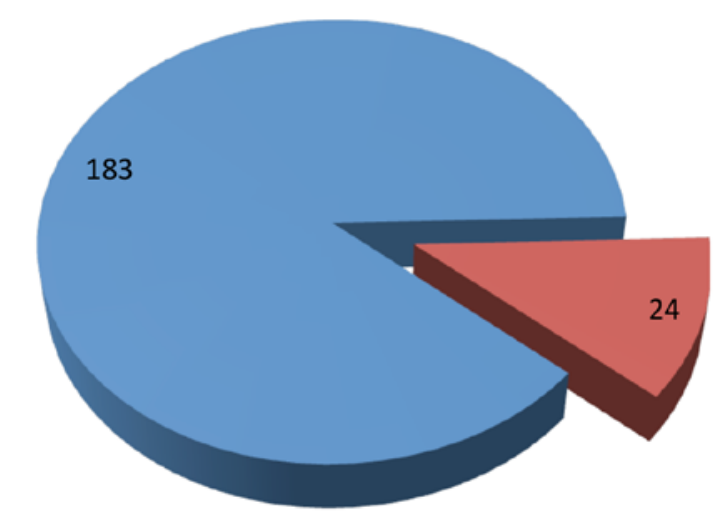

- Manifestes publiés dans le cadre d'un groupe/mouvement

- Manifestes publiés hors du cadre d'un groupe/mouvement et signés par une seule personne

$$
\text { (29 mai 2016) }
$$

Ce graphique relativise l'origine nécessairement collective du manifeste, en donnant une assise statistique à une forme de " manifeste au singulier » dont la plupart des études critiques ne rend pas compte. Si l'on peut confirmer que les manifestes produits et lancés à titre individuel représentent seulement $12 \%$ du corpus (vingt-quatre entrées) et constituent donc un phénomène marginal, une recherche sur leur année de production permet de montrer que la plupart de ces textes ont été produits à partir de 1980. Ce résultat ouvre ainsi une réflexion sur l'adaptabilité du manifeste aux conditions socioéconomiques de son temps et sur le déclin des pratiques collectives au $\mathrm{XX}^{\mathrm{e}}$ siècle $^{2}$.

Les recherches quantitatives rendues possibles par la base de données comportent toutefois certaines limites pour l'étude du

2 D'autres graphiques extraits de la base Manart et commentés par leurs auteurs se trouvent ici.
Figure 2. Data retrieved from Manart by M. Tjell (29 May 2016)

In blue: Manifestos published within a group/movement; in orange: Manifestos published outside of a group/movement and signed by one person.

This graph relativizes the necessarily collective origin of the manifesto by giving a statistical existence to manifestos in the "singular" form, that most critical studies do not take into account. While we can confirm that manifestos produced and issued by individuals represent only 12 per cent of the corpus (24 entries) and therefore constitute a marginal phenomenon, a search by year of their production shows that the majority of these texts were produced as of 1980 . This finding, therefore, invites reflection on the adaptability of the manifesto to the socio-economic conditions of its time and on the decline in the twentieth century of collective practices. $^{2}$

The quantitative research made possible with the database contains certain limitations, however, for the study of the manifesto. Although

2 Other graphs retrieved from the Manart database and commented on by their authors can be found here. 
manifeste. Si ces méthodes enrichissent l'éventail d'approches à disposition du chercheur, l'élargissement considérable du corpus de textes pris en compte par la base des données a tendance à atténuer, pour ne pas dire à effacer, l'impact réel et le pouvoir performatif de chaque manifeste. Assignant un poids équivalent à tous les documents, Manart atténue par exemple l'impact des modèles avantgardistes sur la production manifestaire de la deuxième moitié du $\mathrm{XX}^{\mathrm{e}}$ siècle. Il est toutefois difficile de concevoir l'histoire du manifeste sans prendre en compte les dynamiques d'influence et les renvois intertextuels complexes qui lient les manifestes des néo-avantgardes des années 1960 et les recyclages contemporains du genre à leurs « ancêtres » avant-gardistes. Ici, comme pour la plupart des recherches de type quantitatif, les résultats n'offrent qu'une image schématique et partielle de la réalité. Si ces derniers permettent de poser de nouvelles questions sur l'usage des manifestes et d'en enrichir la compréhension par de nouvelles perspectives d'étude, il convient ensuite de revenir, en spécialiste des domaines artistiques,

aux textes et aux œuvres concernés.

\section{Qu'envisagez-vous pour la pérennité et l'accessibilité de la base de données?}

L'ambition de l'équipe est de faire du projet Manart une plateforme de recherche en open access. Aussi la consultation de la base n'est pas conditionnée à la création d'un compte : tout est visible d'emblée. L'ajout des fac-similés numérisés des documents originaux représente un pas important dans cette direction, car il ouvrirait la base à de nouveaux domaines et à de nouveaux usagers.

Actuellement à ses débuts, un tel développement nécessitera cependant la collaboration et le soutien d'institutions patrimoniales telles que la Bibliothèque nationale de France ou la Bibliothèque Kandinsky, notamment pour les questions de droit et d'archivage these methods enhance the range of approaches available to the researcher, the considerable broadening of the body of texts taken into account by the database has a tendency to diminish, if not erase, the actual impact and performative power of each manifesto. Because it tends to assign an equivalent weight to all documents, Manart diminishes, for example, the impact of avant-garde models on the manifesto production of the twentieth century. However, it is difficult to conceive of the history of the manifesto without taking into account the dynamics of influence and the complex intertextual references that link neo-avant-garde manifestos of the 1960s and contemporary recycling of the genre, to their avant-garde "ancestors." Here, as with most quantitative research, the results offer only a schematic and partial image of reality. While the latter offer the opportunity to ask new questions concerning the use of manifestos and to enhance the understanding of them through new study perspectives, it is advisable to then return, as a specialist in artistic fields, to the texts and works involved.

\section{What plans do you have with regard to the durability and accessibility of the database?}

The team wants to make the Manart project into an open access research platform. That is the reason why consulting the database is not dependent on the creation of an account: everything is instantly visible. The addition of digitalized facsimiles of original documents would represent an important step in this direction because it would open the database to new fields and new users.

Currently in its early stages, such a development will require, however, the collaboration and support of patrimonial institutions such as the Bibliothèque nationale de France or the Bibliothèque Kandinsky, particularly for copyright issues and issues concerning 
pérenne des données. Une première option envisagée prévoit la redirection vers des manifestes déjà publiés en ligne et hébergés au sein d'institutions pérennes, ce qui ferait de Manart une sorte de

« hub » du manifeste sur la toile.

La question de l'hébergement se pose aussi : faut-il être hébergé sur des serveurs universitaires ou institutionnels, ce qui garantit une meilleure pérennité mais impose davantage de contraintes techniques, ou au contraire préserver une sorte d'autonomie et de souplesse technique du projet, ce qui impliquerait de réfléchir à d'autres solutions pour en assurer la pérennité ?

Camille Bloomfield

Université Paris 13 - Pléiade, centre de recherche pluridisciplinaire

Viviana Biroll

Université Paris 1 Panthéon-Sorbonne - Centre de recherche Hicsa (Histoire culturelle et sociale de l'art)

Mette Tjell

Dalarna University - Department of Humanities and Media Studies

Audrey Ziane

Aix-Marseille Université - Temps, Espaces, Langages, Europe Méridionale Méditerranée (TELEMMe)

\section{Références bibliographiques}

BLOOMFIELD Camille \& TJELL Mette (2013). « Les âges d'or du manifeste artistique et littéraire en France : étude contrastive à partir de la base de données Manart ». Études littéraires, 44(3) : 151-163. the long-term archiving of data. A first option under consideration allows for the redirection towards manifestos already available online and stored within permanent institutions, which would make Manart a sort of online manifesto "hub."

There is also the question of storage: should it be stored on university or institutional servers, which would guarantee better durability but impose more technical constraints; or should we preserve a degree of autonomy and technical flexibility for the project, which would require other solutions in order to ensure perpetuity?

Camille Bloomfield

Université Paris 13 - Pléiade, centre de recherche pluridisciplinaire

Viviana Birolli

Université Paris 1 Panthéon-Sorbonne - Centre de recherche Hicsa (Histoire culturelle et sociale de l'art)

Mette Tjell

Dalarna University - Department of Humanities and Media Studies

Audrey Ziane

Aix-Marseille Université - Temps, Espaces, Langages, Europe Méridionale Méditerranée (TELEMMe)

\section{References}

Bloomfield Camille \& Mette Tjell (2013). "Les âges d'or du manifeste artistique et littéraire en France: étude contrastive à partir de la base de données Manart." Études littéraires, 44(3): 151-163. 